\title{
The Design Studies of Bakmi 3 Rasa Visual Identity
}

\author{
Thressia Anastasia ${ }^{1}$ Kurnia Setiawan ${ }^{1 *}$ Herlina Kartaatmadja ${ }^{1}$ \\ ${ }^{1}$ Visual Communication Design, faculty of art and Design, Universitas Tarumanagara, Jakarta, Indonesia \\ *Corresponding author. Email: kurnia@fsrd.untar.ac.id
}

\begin{abstract}
The rapid development of culinary business leads the enhancement of competition between competitors who offer the same product. Thus, it encourages business owners to maintain or improve their business image to be known by the wider community through rebranding. Bakmi 3 Rasa is the first pork noodle in South Jakarta, offering unique products from family recipes. Unfortunately, Bakmi 3 Rasa has not had a proper visual identity yet. This research studied the visual identity design process of Bakmi 3 Rasa. The research was qualitative research. The object of research was the visual identity of Bakmi 3 rasa. This research was conducted in Jakarta from August to December 2020. The methodology used in this design was 5 steps of design by Robin Landa, that consist of Orientation, Analysis, Strategy, Design Concept and Design Implementation. The method of collecting data in this design was through interviews and literature study. The result of this design was in the form of a new visual identity and its application to the Graphic Standard Manual (GSM) book. Visual identity was conducted using a minimalist concept, unique and has a friendly element. Through this redesign, it is expected that Bakmi 3 Rasa will have a visual identity with distinctive features that can stick in the minds of consumers. Thus, Bakmi 3 Rasa can be recognized, remembered and competed with similar competitors that continue to emerge.
\end{abstract}

Keywords: Design, bakmi, visual identity

\section{INTRODUCTION}

Food is a basic needs other than clothing and shelter that are highly important for humans in order to sustain their lives. Thus, business potential in the culinary sector is increasingly developing, both the development of the food menu or the variants offered that are increasingly numerous and varied.

Based on the statements of the Minister of Industry, Agus Gumiwang Kartasasmita and the Director General of Agro Industry at the Ministry of Industry, Abdul Rochim, in their statements in the media, they predicted that the food and beverage industry will grow about $3 \%$ and be better than the previous quarter [1].

The development of food industry leads many competitors who offer the same product compete to attract attention of consumers in order to buy the product. According to Cenadi $(1999 ; 71)$, one way to compete with these growing competitors is to create a graphic identity that can display the brand image. Big companies are aware of the importance of graphic identity for their success. Therefore, it needs to create and maintain a strong graphic identity for a brand [2]. In her book Asian Meals, Marie Wilson stated that no matter where it comes from, there is no doubt that noodles are the most consumed food after rice, in China and other Asian countries [3].

Noodles can be the second staple food for consumers other than rice, the carbohydrate content in noodles makes this food a food substitute for rice by consumers (Ramadhan,
2017) [4]. Noodles as the favorite foods of the Indonesian people have had development and innovation. Currently, Processed noodles are not only limited to boiled or fried noodles as is usually common in society.

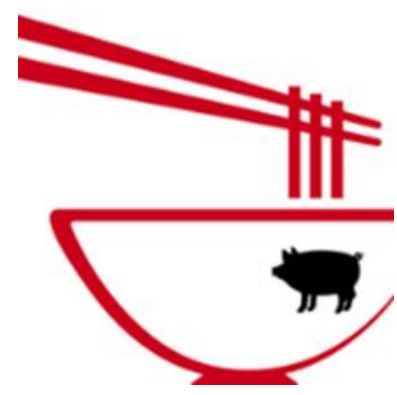

Figure 1 Visual identity of bakmi 3 rasa

Bakmi 3 Rasa is a non-halal food business founded at the end of 2016 that initially only used recipes from the family and only used online delivery services such as Go Food or Grab Food. Furthermore, Bakmi 3 Rasa culinary business grew rapidly. With the various efforts, Bakmi 3 Rasa currently has two branches. There are at Mall Alam Sutera and Blok M. Besides, customer can order through online food delivery services such as Go-Food, Grab Food. Bakmi 3 Rasa can also be ordered through online marketplaces such as tokopedia with the Pre Order system. However, Bakmi 3 Rasa does not have a good visual 
identity. Based on the criteria of good visual identity, the visual identity of Bakmi 3 Rasa is now simple but does not display a brand image, not well known by the public and it does not follow the trend, rigid, less attractive. Thus, it is difficult to attract people's attention, besides having visual graphics that can make competitor. In addition, there is still a lack of application of the visual identity used in every Bakmi 3 Rasa media to strengthen the product image.

According to Febriansyah (2011), Branding affects significantly toward brand image, in which the brand image is consumer confidence in the brand [5].

Therefore, it is necessary to design a new visual identity and promotional media to emphasize the image of the culinary business and promote the culinary business. Thus, it can be recognized by all people.

In accordance with this explanation, the writer is interested in redesigning a new visual identity that can strengthen the product image and also the character of Bakmi 3 Rasa.

\section{BACKGROUND}

Redesigning this visual identity requires several theories to serve as a theoretical basis to emphasize the issues raised. Brand is very important and needed for the company because it can represent the company's products. The brand has developed, not just a brand or trade name of a product, or a company related to things that can be seen directly through the human senses, such as brand names, logos, character images, impressions, perceptions and perceptions in the minds of consumers (Landa , 2006) [6].

The efforts conducted by a company to change customer perception toward their product is by redesign or rebranding. The essence of the factors of a company rebranding is the pressure and priority of the company. This covers the scope of company goals, consumer and competitor pressure, changing a brand from a visual identity form, brand names and slogans to comprehensive strategic decisions.

Visual identity is an important elements in a company used as a bridge to unite various contexts, consumers, as a symbol of distinctive features that can differentiate and represent the company's image [7]. Therefore, redesigning visual identity must pay attention to the consistency of branding standards, and be able to communicate the meaning and quality according to the company's target market.

This design process uses the design stages based on Robin Landa [8], as follow:

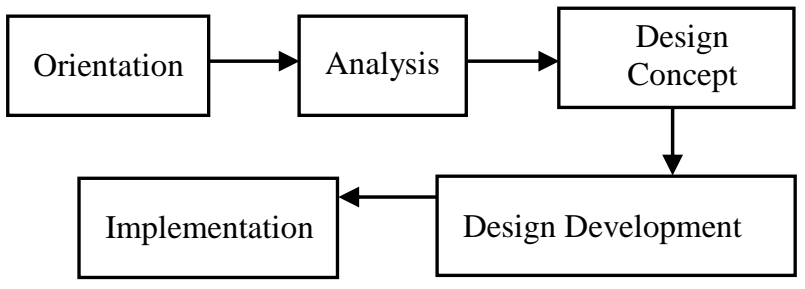

Figure 15 steps of design
A. Orientation

It is collecting information and data to be re-analyzed and conduct a review of what the problem is and what happened in the field that will then be further reviewed at the analysis stage.

B. Analysis

The second step of this process is analyzing and extracting data to understand and assess. This step can be conducted by collecting questions that can help analyzing the problem. In this analysis, data can be collected to formulate strategies and solutions.

C. Design Concept

This stage is important because it can generate strong ideas to support and strengthen the design design process. This can be conducted by paying attention to elements, information, related to the brand carefully. The final results of the ideas obtained at this stage will be collected and developed to be continued in the design process.

D. Design Development

Design step can be carried out by exploring through manual sketches in pencil, and develop designs on paper. Then, it is proceeded with a rough sketch to determine the idea and comprehensively by visualizing the design concept in the form of a mockup to give an overview.

E. Implementation

Implementation is design result or execution carried out after passing the above steps, through implementation in the form of mockups or even digital priting.

\section{METHODS}

This research is qualitative. The research object was the visual identities of Bakmie 3 Rasa. Research site was in Jakarta in August - December 2020. The method used was literature study and interviews with the owner of Bakmi 3 rasa. The researcher applied a design methodology based on the theory of Robin Landa, it is 5 Steps of Design:

\section{A. Orientation}

This design was started with orientation stage. The authors collected primary data through conducting interviews with the owner of Bakmi 3 Rasa to find out in detail the information related to the business and the data needed in this design. The author obtained secondary data through literature study through books and reliable internet sources to collect the data needed in this design as well as for theoretical foundations.

B. Analysis

After collecting data about Bakmi 3 Rasa, authors analyzed the problems and determined the image of Bakmi 3 Rasa then drew conclusions, followed by formulating the right strategy through a Design brief. 


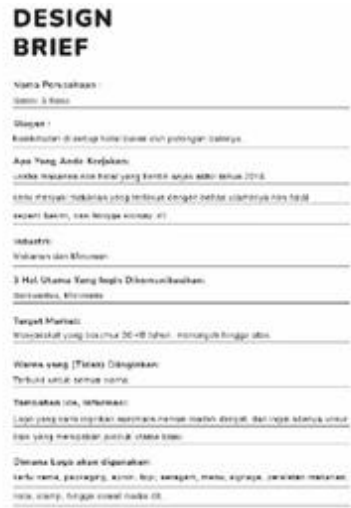

Figure 2 Design brief

C. Design Concept

Concept formation consists of 4 stages, such as preparation to find basic ideas (insight), incubation and illumination to find concepts, and finally verification as a form of evaluation and concept testing.The author made mind mapping and moodboards to help determine the concept of visual identity and color palettes that can be used in designing the visual identity of Bakmi 3 Rasa. After obtaining a few keywords, it was proceeded by making a Morphological Matrix based on keywords. The author tried to explore various possible design elements to make it easier to create visuals and help generate new ideas. Morphological Matrix was made based on the theory of change in shape, such as simplification. The object was simplified in such a way that the appearance was as an icon/symbol. Even though the view has been simplified, the object could still be perceived.

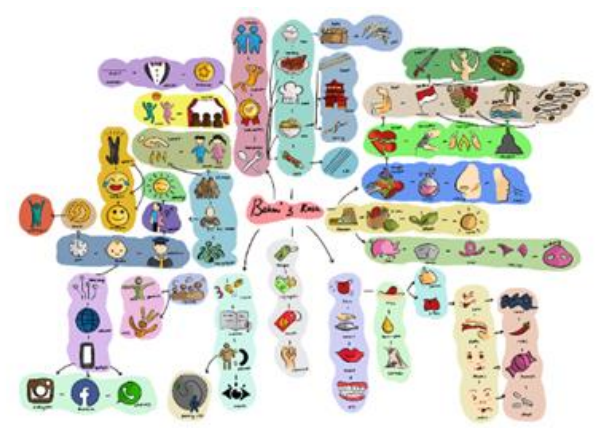

Figure 3 Mind mapping

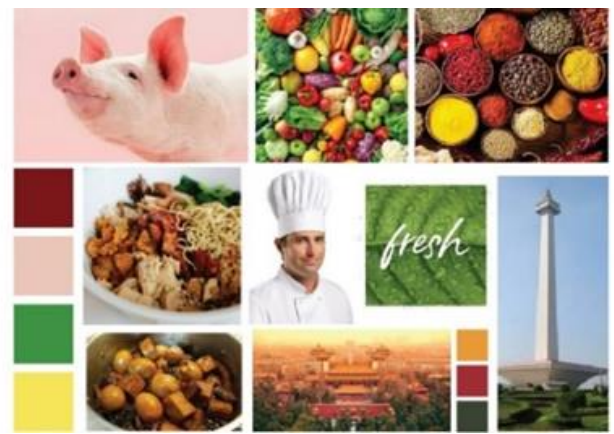

Figure 4 Moodboard

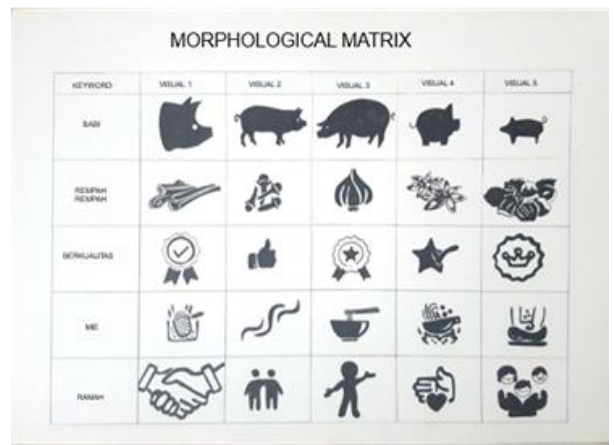

Figure 5 Morphological matrix (a)

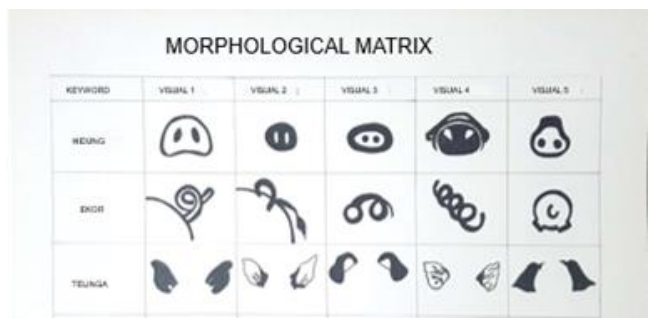

Figure 6 Morphological matrix (b)

D. Design Development

After obtaining keyword and making Morphological Matrix, the author conducted design development through several stages, such as:

a. Small sketch

The author explored through small hand-drawn sketches using a pencil and develops designs on paper that can define various visual possibilities.

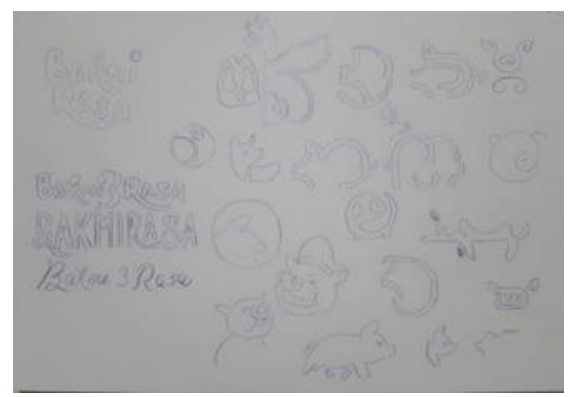

Figure 7 Small sketch 
b. Big Sketch

After making a small sketch, author continued making a big sketch into a digital version to determine the best ideas that can be used to describe the design concept. Big sketches are made in digital form.

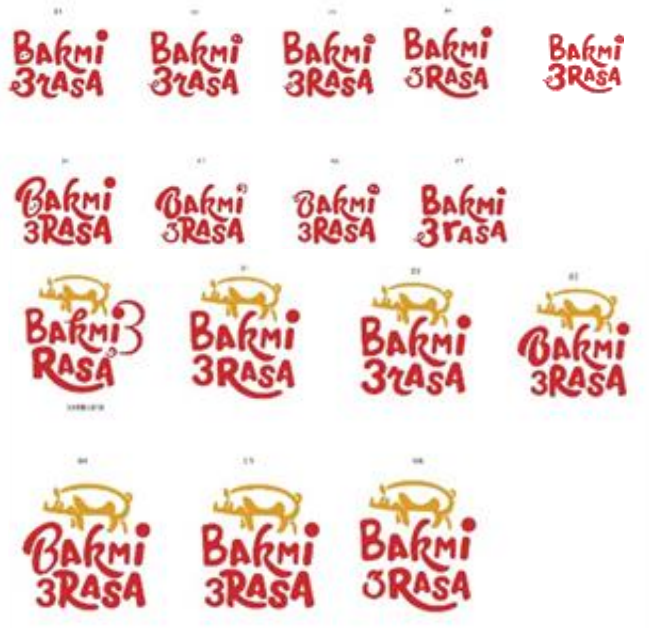

Figure 8 Big sketch

c. Comprehensive

Through a big sketch, it will produce several visual identity alternatives, from the visual identity alternative, the best one among the alternatives has been made. After selecting the visual identity, it would be continued in the form of a mockup to provide an overview.

d. Implementation

All design result would be tidied up and ready to be executed into the selected media either digital or print.

\section{FINDINGS AND DISCUSSIONS}

A. Analysis of target audience

1. Geographic
a. Region
: Jakarta
b. Area
: Areas that become tourist attractions and place that has culinary spots

2. Demographic
a. Gender
: men and women
b. Age
: 20-40 years
c. Occupation
: Children, Student, Collage
Student, Worker, Family
d. Economic Status : Upper Middle (SES AB)

Based on Nielsen data in 2010, the SES grouping is as follows [9]:

SES Grouping Standards

SES Range Grouping Type

SES A

$\begin{array}{ll}\text { SES B } & : 2.000 .001-3.000 .000 \\ \text { SES C1 } & 1.500 .001-2.000 .000 \\ \text { SES C2 } & : 1.000 .001-1.500 .000 \\ \text { SES D } & 700.001-1.000 .000 \\ \text { SES E } & :<700.000\end{array}$

3. Lifestyle

Modern lifestyle, Experience seekers, Culinarians, Food Bloggers, culinary connoisseurs, Food Vloggers.

4. Behavior

a. Consumers who attention to the quality and quality of a food.

b. Consumers who like culinary

c. Consumers who like to hang out with family and friends, tell stories or discuss work.

B. SWOT analysis

1. Strength

a. Food prices are relatively affordable to the target audience,

b. There are dining menu. The large number of processed foods made from pork makes many choices of this culinary,

c. It is easy to reach and it can be ordered via online such as Go Food, Whatsapp, Tokopedia and others.

2. Weakness

a. It is lack of promotion, so that the target audience is not very familiar with Bakmi 3 Rasa,

b. The brand image of Bakmi 3 Rasa is not well known in the Jakarta area.

c. It offers Non-Halal food, so it can't reach all groups.

3. Opportunity

a. Creating varied menus,

b. There are plans to open new branches in the Jakarta area.

4. Threat

a. There is competition between similar Bakmi culinary and incessant promotions,

b. There is soaring prices of raw materials such as meat have made restaurants have to increase the prices of existing food / beverages,

c. There are changes in people's tastes that change rapidly, if there is no innovation.

d. There are many choices of restaurants around. This makes many visitors choose other restaurants

C. Design concept

1. Media Concept

The main media that would be made was Bakmi 3 Rasa's new visual identity and its application to the Graphic Standard Manual. It was conducted to guide in the application of Bakmi 3 Rasa's visual identity in the future. Thus, in understanding, it can maintain brand consistency, emphasizing the image 
of promoting the culinary business so that it can be recognized by the whole community.

2. Visual Identity Concept

The design of visual identity can't be separated from the concept. The concept used in the design of the visual identity of Bakmi 3 Rasa was "visualizing" a visual identity that can present a brand image and has a friendly element in a unique and minimalist appearance.

Bakmi 3 Rasa's new visual identity was designed with a minimalist and simple concept. It was made by combining a strong brand name and typography. Typographic forms in visual identity were made manually without existing fonts. It made the product more unique and attractive. Each letter was made with a rounded element to make it seem friendly and not stiff. The elements combined with the font are simplified to ease and the use of these elements is inspired by a pig as the main product of Bakmi 3 Rasa.

3. Color Concept

The color used is a bright color that can attract people's attention easily. The color chosen is red (bright red). It is taken from a moodboard that has been made and based on color psychology, red can be used to increase appetite, stimulate appetite and attract attention. person.

4. Supergraphic Concept

Supergraphic is as a support in application to the media. It was created to strengthen and develop Bakmi 3 Rasa communication visually. The elements in supergraphic are inspired by elements of visual identity along with the main products sold by Bakmi 3 Rasa. Supergraphic was made with thick thin lines and digital hand drawing techniques in accordance with the characteristics and match the visual identity of Bakmi 3 Rasa.

D. Picture

1. Visual identity

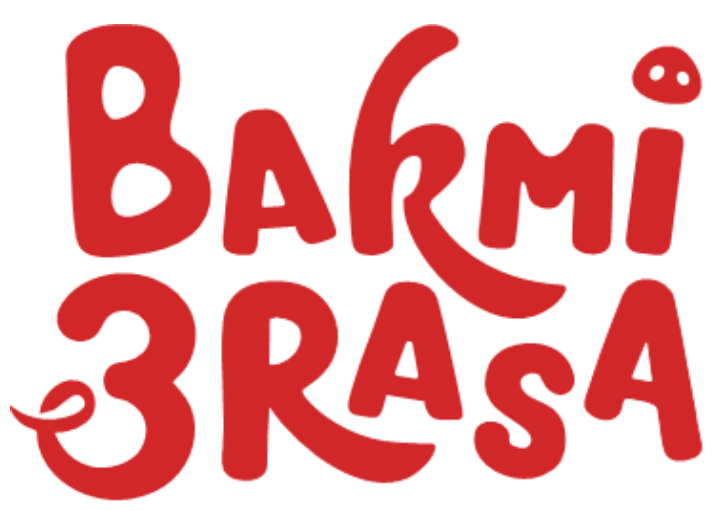

Figure 9 Visual identity of bakmi 3 rasa
2. Supergraphic

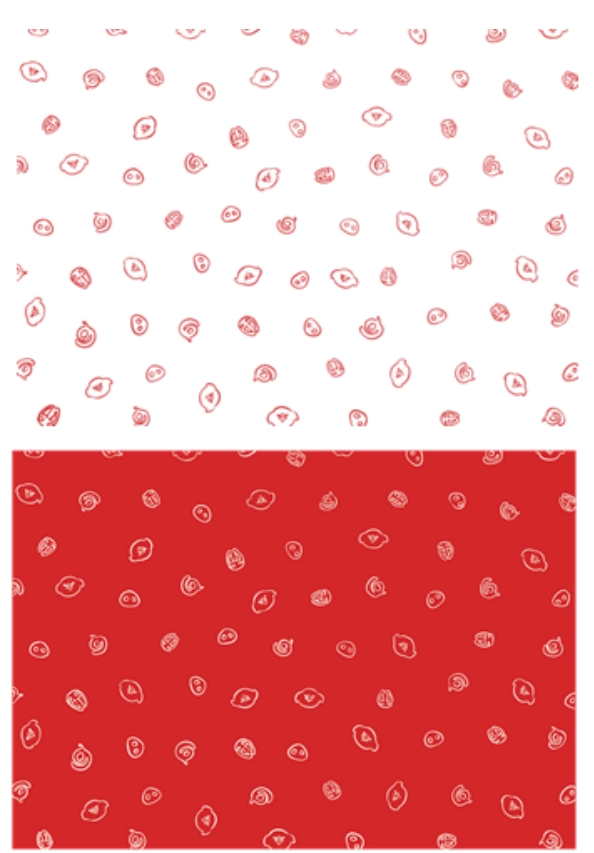

Figure 10 Supergraphic of bakmi 3 rasa

3. Graphic Standard Manual
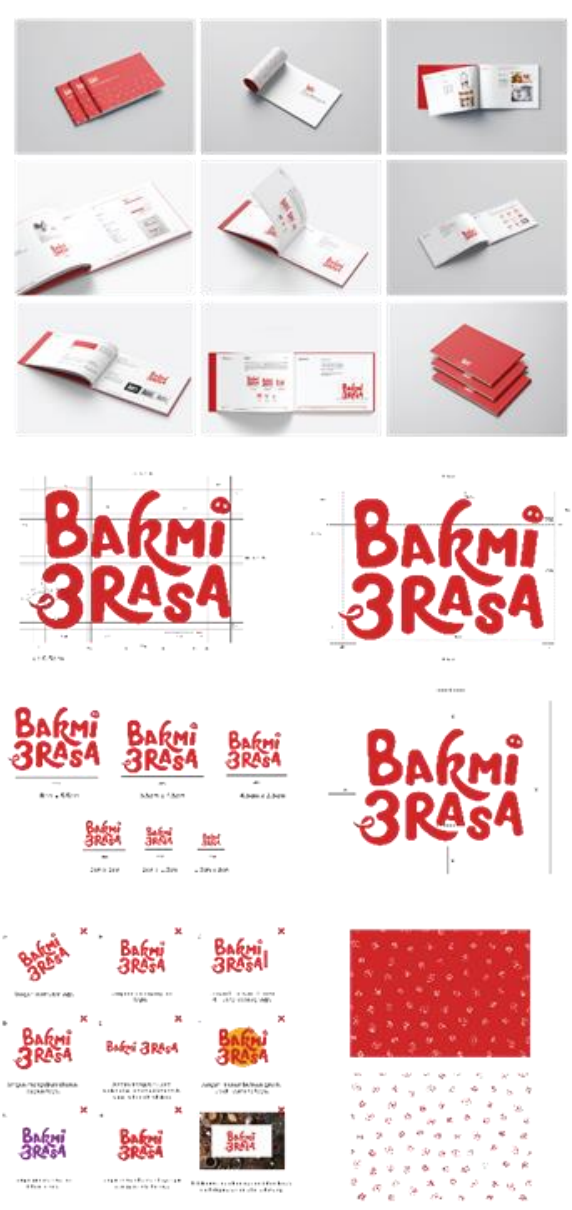


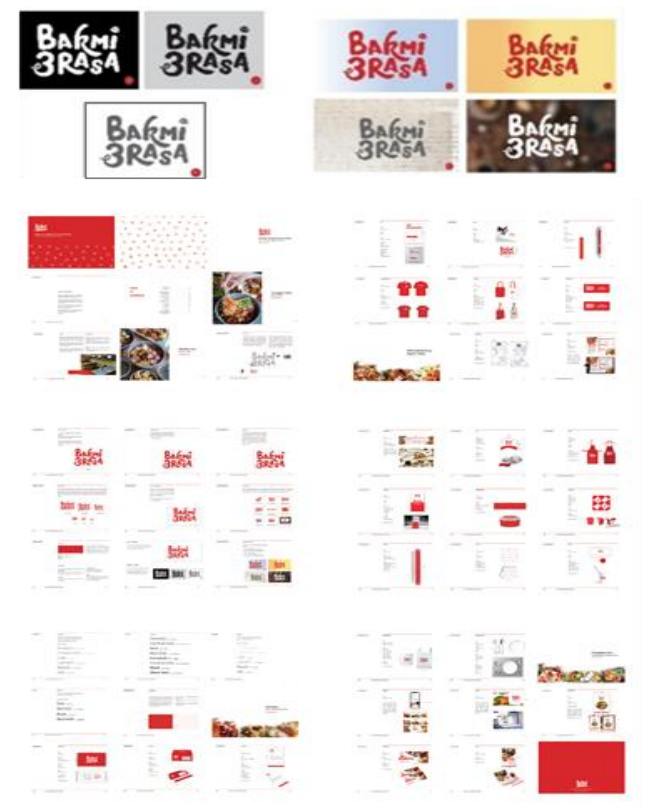

Figure 11 Graphic Standard Manual of Bakmi 3 Rasa

4. Media for Application of Visual Identity a. Stationary set

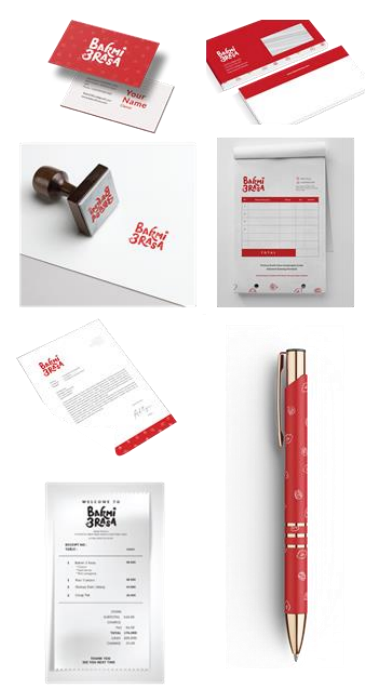

Figure 12: Stationary set of Bakmi 3 Rasa b. Uniform

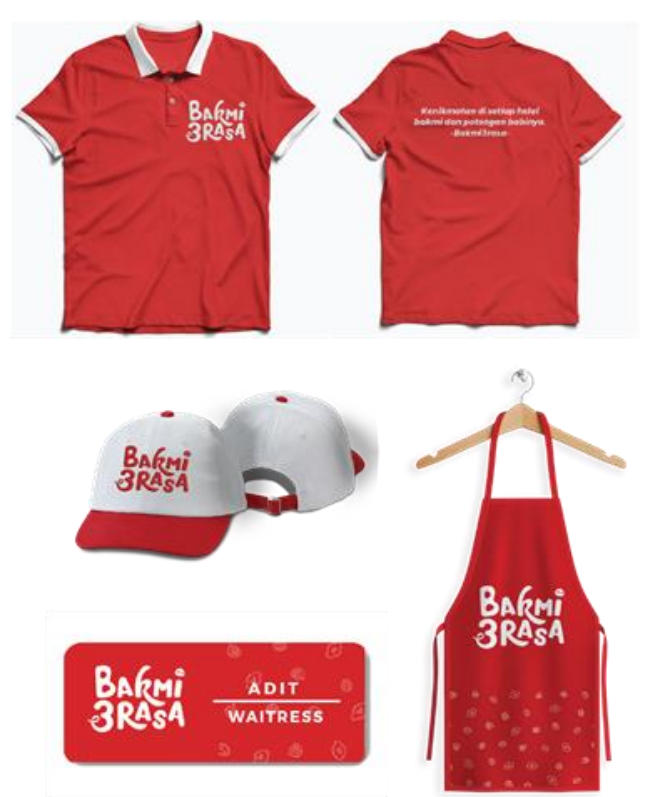

Figure 13: Uniform of bakmi 3 rasa

c. Promotion media
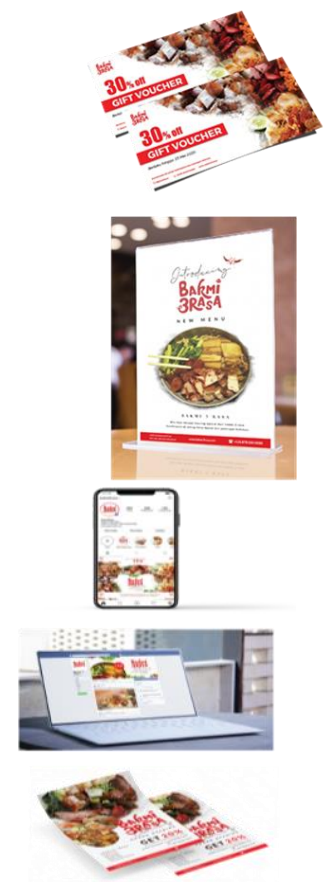

Figure 14 Promotion media of bakmi 3 rasa 


\section{d. Amenities}

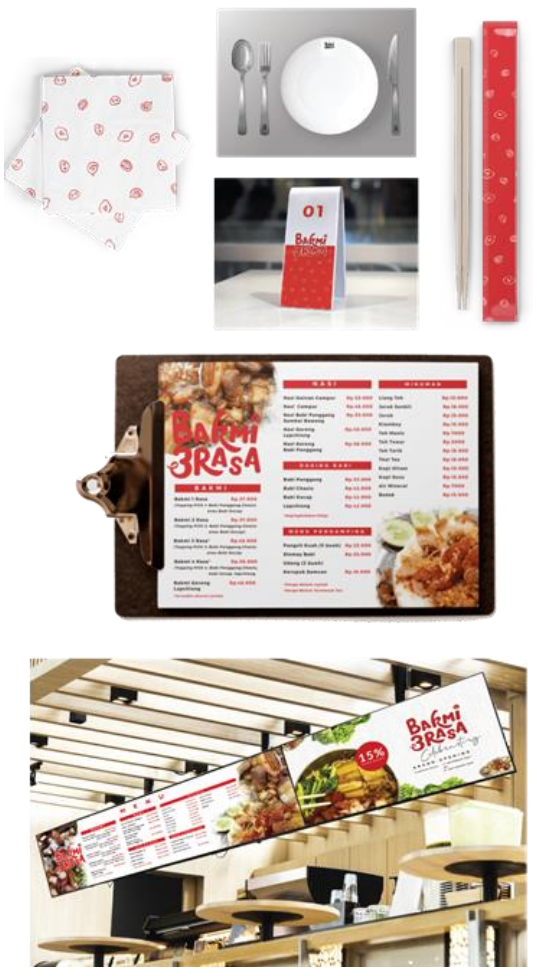

Figure 15 Amenities of bakmi 3 rasa e. Packaging
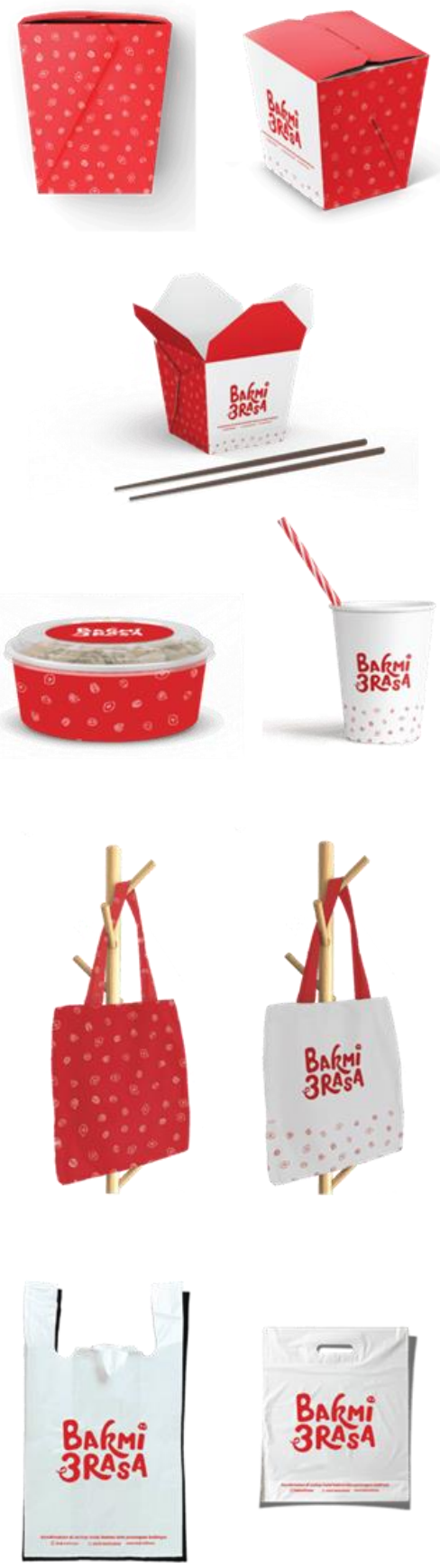

Figure 16: Amenities of Bakmi 3 Rasa

\section{CONCLUSIONS}

Visual identity design uses 5 stages of design (5 Steps of Design, Robin Landa): Orientation, Analysis, Strategy, Design Concept and Design Implementation), It generates redesign below:

a. The concept is minimalistic, unique and it has a friendly element which is translated into visual, 
supergraphic, color, and Graphic Standard Manual Bakmi 3 Rasa.

b. It is used manually fonts without existing fonts with a rounded touch that gives a unique and not stiff impression.

c. The elements combined with the visual identity represent the simplified shape of the nose and tail of a pig as the main product of Bakmi 3 Rasa. Supergraphic uses an illustration form that fits and has a unity with visual identity.

d. It uses one color, red based on color psychology, can be used to increase appetite, stimulate appetite and attract attention and oriental nuances.

e. Standard Manual Graphic uses a clean layout so that it fits the concept and has a unity with each other.

\section{ACKNOWLEDGMENT}

This writing is supported by Mr. Aditya and Mrs. Nita as the owner of Bakmi 3 Rasa and Tarumanagara University Research and Community Service (LPPM).

\section{REFERENCES}

[1] Rantung,Ferdi. (2020). Industri Makanan Minuman Diprediksi Tumbuh 3\% Hingga Akhir Tahun 2020. Date of Access: 14 January 2021 from: https:// economy.okezone.com/read/2020/09/19/320/2280394/i ndustri-makanan-minuman-diprediksi-tumbuh-3-

hingga-akhir-2020

[2] Cenadi, C. S. (1999). Corporate Identity Sejarah Dan Aplikasinya. Nirmana, 1(2).

[3] Wilson, Marie. (2011). 30-Minutes ASIAN Meals:250 Quick, Tasty \& Healthy Recipes from Around Asia. North Claredon: Tuttle Publishing

[4] Ramadhan, R. R. 2017. Mutu Organoleptik Mie Basah dengan Penggunaan Tepung Ampas Kedelai. Thesis. Universitas Brawijaya. Malang.

[5] Febriansyah, "Pengaruh Pengaruh Logo (Rebranding Terhadap Citra Merek Pada PT.Telkom Tbk Di Bandar Lampung" Ekonomika Bisnis, Vol.5, No. 2, Juli 2014: 101-106

[6] Landa, Robin. (2011). Graphic Design Solutions, United States: Clark Baxster Designing Brand Identity

[7] Rustan, Surianto. (2009). Mendesain Logo. Jakarta: PT Gramedia Pustaka Utama.
[8] Landa, Robin. (2011). Graphic Design Solutions, United States: Clark Baxster Designing Brand Identity

[9] AC Nielsen. (2010). SES (Socio-Economic Status) Indonesia. Date of access: 20 September 2020 from: https://vidinur.net/2010/11/04/ses-socio-economicstatus-ndonesia/ 